\title{
Mapping cold-water coral biomass: an approach to derive ecosystem functions
}

\author{
L. H. De Clippele ${ }^{1}$ (1) L. Rovelli ${ }^{2}$ - B. Ramiro-Sánchez ${ }^{1}$ - G. Kazanidis ${ }^{1}$ • \\ J. Vad ${ }^{1} \cdot$ S. Turner ${ }^{1} \cdot$ R. N. Glud ${ }^{3,4} \cdot$ J. M. Roberts ${ }^{1}$
}

Received: 3 June 2020/Accepted: 17 November 2020/Published online: 4 December 2020

(C) The Author(s) 2020

\begin{abstract}
This study presents a novel approach resulting in the first cold-water coral reef biomass maps, used to assess associated ecosystem functions, such as carbon (C) stock and turnover. We focussed on two dominant ecosystem engineers at the Mingulay Reef Complex, the coral Lophelia pertusa (rubble, live and dead framework) and the sponge Spongosorites coralliophaga. Firstly, from combining biological (high-definition video, collected specimens), environmental (extracted from multibeam bathymetry) and ecosystem function (oxygen consumption rate values) data, we calculated biomass, $\mathrm{C}$ stock and turnover which can feed into assessments of $\mathrm{C}$ budgets. Secondly, using those values, we employed random forest modelling to predictively map whole-reef live coral and sponge biomass. The whole-reef mean biomass of $S$. coralliophaga was estimated to be $304 \mathrm{~T}$ (range
\end{abstract}

Topic Editor Stuart Sandin

Electronic supplementary material The online version of this article (https://doi.org/10.1007/s00338-020-02030-5) contains supplementary material, which is available to authorized users.

L. H. De Clippele

Laurence.de.clippele@gmail.com

J. M. Roberts

murray.roberts@ed.ac.uk

1 Changing Oceans Research Group, School of GeoSciences, University of Edinburgh, Edinburgh, United Kingdom

2 Institute for Environmental Sciences, University of KoblenzLandau, Landau, Germany

3 Nordcee, Department of Biology, University of Southern Denmark, Odense, Denmark

4 Department of Ocean and Environmental Sciences, Tokyo University of Marine Science and Technology, Tokyo, Japan
168-440 T biomass), containing $10 \mathrm{~T} \mathrm{C}$ (range 5-18 T C) stock. The mean skeletal mass of the coral colonies (live and dead framework) was estimated to be $3874 \mathrm{~T}$ (range 507-9352 T skeletal mass), containing a mean of $209 \mathrm{~T}$ of biomass (range 26-515 $\mathrm{T}$ biomass) and a mean of $465 \mathrm{~T} \mathrm{C}$ (range 60-1122 T C) stock. These estimates were used to calculate the $\mathrm{C}$ turnover rates, using respiration data available in the literature. These calculations revealed that the epi- and microbial fauna associated with coral rubble were the largest contributor towards $\mathrm{C}$ turnover in the area with a mean of $163 \mathrm{~T} \mathrm{C}^{-1}$ year $^{-1}$ (range 149-176 T C year $^{-1}$ ). The live and dead framework of $L$. pertusa were estimated to overturn a mean of $32 \mathrm{~T} \mathrm{C}$ year $^{-1}$ (range

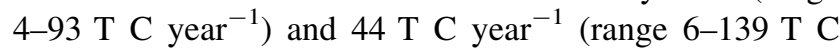
year $^{-1}$ ), respectively. Our calculations showed that the Mingulay Reef overturned three to seven (with a mean of four) times more $\mathrm{C}$ than a soft-sediment area at a similar depth. As proof of concept, the supply of $\mathrm{C}$ needed from surface water primary productivity to the reef was inferred. Since 65-124 T C year ${ }^{-1}$ is supplied by natural deposition and our study suggested that a mean of $241 \mathrm{~T} \mathrm{C}$ year $^{-1}$ (range 160-400 T C year ${ }^{-1}$ ), was turned over by the reef, a mean of 117-176 T C year ${ }^{-1}$ (range 36-335 T C year ${ }^{-1}$ ) of the reef would therefore be supplied by tidal downwelling and/or deep-water advection. Our results indicate that monitoring and/or managing surface primary productivity would be a key consideration for any efforts towards the conservation of cold-water coral reef ecosystems.

Keywords Biomass mapping - Ecosystem functions . Carbon cycle $\cdot$ Predictive mapping - Cold-water coral reef 


\section{Introduction}

Cold-water coral (CWC) reefs are important marine ecosystems, as they are hotspots of biomass and biodiversity that provide a wide range of ecosystem processes and services (Armstrong et al. 2012) through carbon (C) cycling, $\mathrm{C}$ burial, fisheries and new opportunities for pharmaceutical development (Foley et al. 2010; Skropeta 2008; van Oevelen et al. 2009). Since CWC ecosystems occur in the aphotic zone, they depend on the supply of particulate organic matter (POM) through oceanographic processes such as tidal downwelling and internal waves (Roberts et al. 2006). Climate change models predict global increases in ocean temperatures, as well as associated increases in ocean acidification and decreases in ocean oxygen levels (IPCC 2018). These changes might affect ocean currents, organisms' metabolic demands and the export flux of POM, ultimately affecting the amount of biomass deep-sea ecosystems can support and consequently affecting ecosystem processes such as $\mathrm{C}$ cycling (Sweetman et al. 2017). Quantifications of the current status of ecosystems in terms of biomass and $\mathrm{C}$ turnover are thus needed to better comprehend future changes in ecosystem functions.

Calculating the amount of biomass in a benthic reef ecosystem is important in a number of ways. Firstly, by taking respiration or oxygen consumption measurements, biomass can be used as a proxy for calculating $\mathrm{C}$ turnover and thus ecosystem functioning (van Oevelen et al. 2009). From $\mathrm{C}$ turnover, one can quantify the importance of the different supply mechanisms of POM from surface water primary productivity (PP) to the reef, ranging from natural deposition to flow-driven upwelling and advection. Finally, biomass values can also be used to calculate $\mathrm{C}$ standing stock, which could feed into assessments of $\mathrm{C}$ budgets and help evaluate the importance of CWC reefs as carbonate sinks or sources (Burrows et al. 2014; Titschack et al. 2015).

Existing marine biomass assessments can be based on allometric (unequal growth rate) or isometric (equal growth rate) relationships (Dornelas et al. 2017; Benoist et al. 2019; Madin et al. 2020). Compared to tropical corals, cold-water corals have low metabolic rates and allometric data are currently not available. Biomass data can also be measured with small-scale localised samples collected with box cores, Van Veen grabs or from fishing activities (Bohnsack and Harper 1988; de Froe et al. 2019; Kazanidis and Witte 2016; van Oevelen et al. 2009). These single spot measurements, however, do not reflect the spatial heterogeneity of natural ecosystems (de Froe et al. 2019). While terrestrial studies can exploit remote sensing (e.g. satellite imagery) in combination with field measurements to map biomass at the ecosystem scale (Baccini et al. 2008), this approach is not applicable to deep-sea habitats. Despite increased availability of continuous photographic seafloor maps (Bodenmann and Thornton 2017; Thornton et al. 2016) wide-scale applications remain scarce, with no maps available for CWC reefs biomass to date.

The reef-forming coral Lophelia pertusa and the massive sponge Spongosorites coralliophaga are two important ecosystem engineers (sensu Jones et al. 1997) as they are both key to sustaining healthy CWC reef ecosystems (Roberts 2005; Wheeler et al. 2007; Kazanidis et al. 2016, 2018a). The three-dimensional complex framework of live L. pertusa alters the chemistry and currents of its surrounding environment, but it is mostly the dead coral rubble and framework that provide microhabitats for a diverse fauna (Henry and Roberts 2007; Buhl-Mortensen et al. 2010). Similarly, the sponge $S$. coralliopaga is an ecosystem engineer that hosts a diverse and rich epifaunal community (Kazanidis et al. 2016).

A novel approach is proposed here to map whole-reef biomass of L. pertusa and $S$. coralliophaga using surface area data from high-definition (HD) videos in combination with field measurements and predictive modelling techniques based on the CWC Mingulay Reef (MR) Complex, one of the best studied reefs in the world (Davies et al. 2009; De Clippele et al. 2017; Douarin et al. 2014; Duineveld et al. 2012; Findlay et al. 2014; Henry et al. 2010; Henry and Roberts 2014; Kazanidis and Witte 2016; Moreno-Navas et al. 2014; Roberts et al. 2009, 2005). Carbon stock and turnover were then assessed from the predicted biomass values using oxygen consumption and respiration rates available through the literature.

\section{Methodology}

\section{Location}

Our study area, known as Mingulay Reef area 01 (MR1), lies on the east-west oriented ridge of the MR Complex off the west coast of Scotland (Fig. 1). The MR1 compromises of over 500 small reef mounds, referred to as "minimounds" (De Clippele et al. 2017). These "minimounds" are on average $8 \pm 5 \mathrm{~m}$ (SD) high, $44 \pm 6 \mathrm{~m}$ (SD) long and $30 \pm 11$ (SD) $\mathrm{m}$ wide (De Clippele et al. 2017, 2019a). The shallowest point on the ridge rises to less than $100 \mathrm{~m}$ water depth, and the deepest point reaches $260 \mathrm{~m}$. Live coral can be found between 120 and $190 \mathrm{~m}$ depth (Roberts et al. 2009; De Clippele et al. 2017). The MR Complex is a hotspot of marine biodiversity which was designated as a marine protected area in 2010 (Marine Scotland Science 2016). The majority of the MR is covered with coral rubble (Roberts et al. 2005) which hosts a rich associated fauna of 


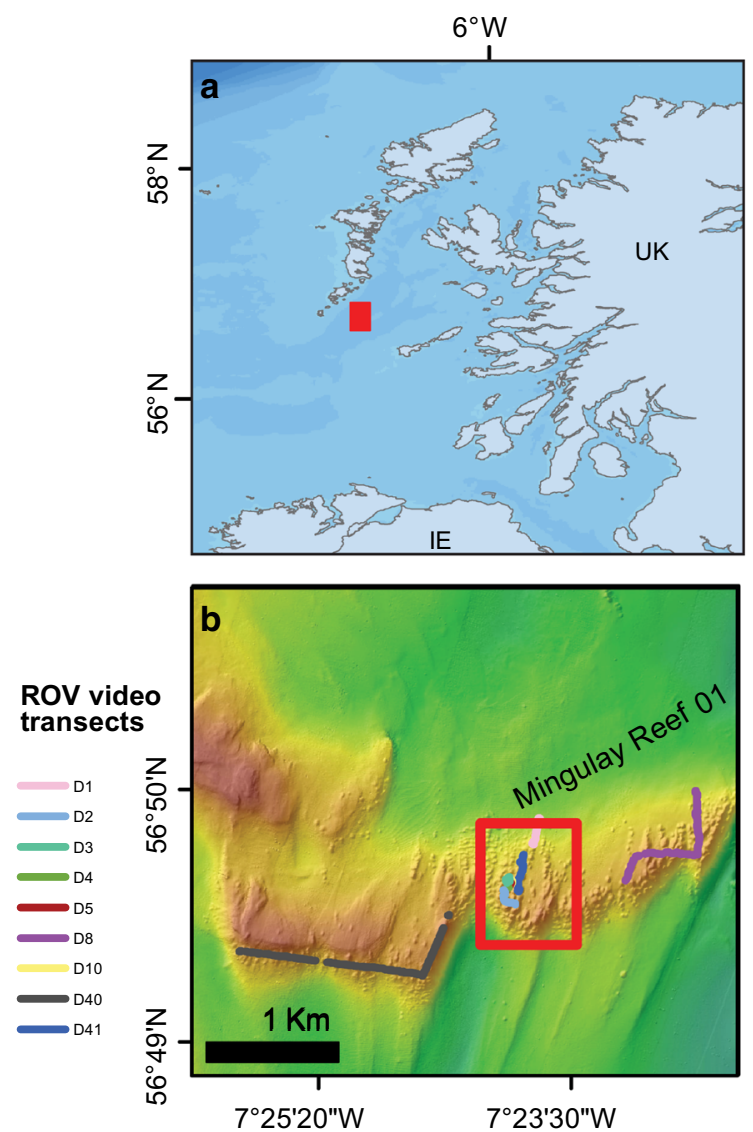

Fig. 1 a Location of the Mingulay Reef Complex in the Hebridean sea off the west coast of Scotland. b Mingulay reef 01 with the red square showing the location of the high-resolution map (c). c Middle section of the Mingulay reef with a resolution of $0.35 \times 0.35 \mathrm{~m}$

anthozoans, ophiuroids and sponges (Henry and Roberts 2007, Kazanidis et al. 2016). Even though the MR complex could, in the future, be affected by ocean warming, due to its relatively shallow location, there is no immediate evidence of ocean acidification at the MR Complex (Findlay et al. 2013, 2014; Thresher et al. 2015; Morato et al. 2020) and it might therefore act as a refuge (De Clippele et al. 2017). There are two hydrographic mechanisms that supply the MR Complex with nutrients. Firstly, hydraulic flow and internal waves cause rapid tidal downwelling (Davies et al. 2009) supplying warmer and nutrient-rich water from the surface. Secondly, POM is also supplied via re-suspended particles during peak tidal flows (Davies et al. 2009).

\section{Data}

\section{Biological data}

HD video data were collected during the Changing Oceans 2012 expedition, RRS James Cook cruise 073 (BODC 2015), using the remotely operated vehicle (ROV)

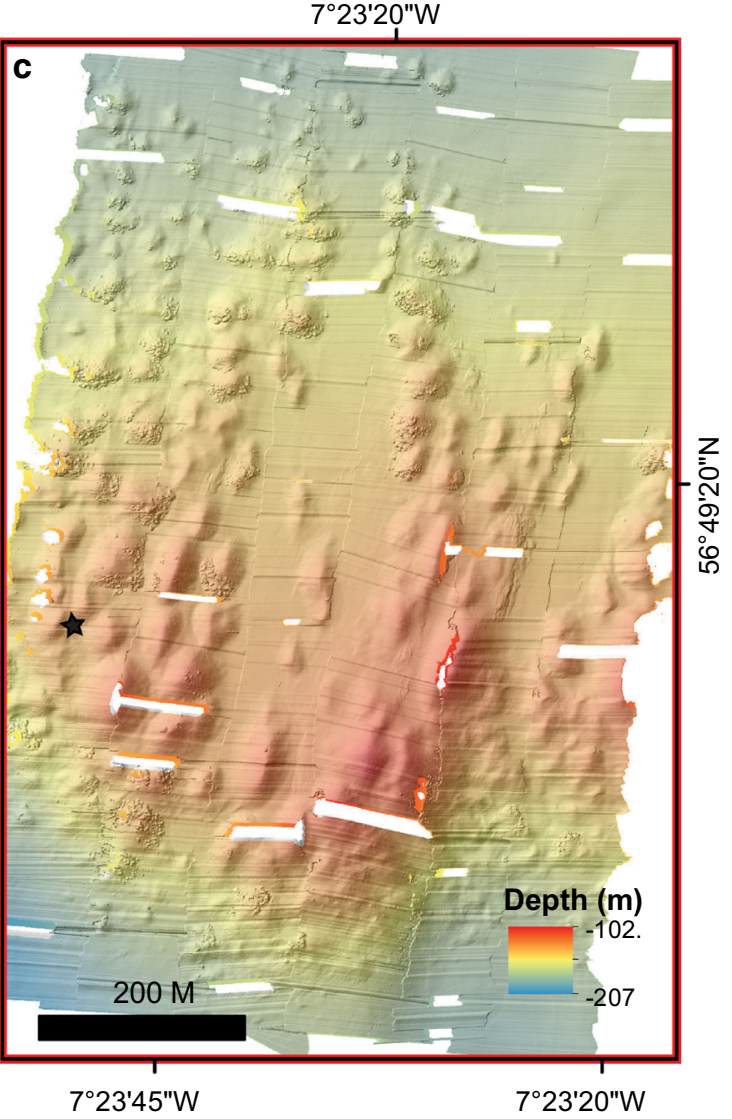

where the minimounds are visible (De Clippele et al. 2017). The black star indicates the location of the aquatic eddy co-variance that was deployed in 2012 during the Changing Oceans 2012 (JC073) expedition

Holland-1 (more details in De Clippele et al. 2017). Using the software VLC v.3.0.7, video frames were extracted whenever the coral L. pertusa or the sponge S. coralliophaga was present (Table 1, Fig. 2).

Spongosorites coralliophaga and L. pertusa specimens were collected during the 2012 expedition. Spongosorites coralliophaga specimens were initially collected for sponge feeding ecology experiments (Kazanidis and Witte 2016) for which their wet and dry weight and respiration measurements were collected and used in this study (Table 2) (Kazanidis et al. 2018a,b).

Lophelia pertusa fragments were collected from 141 to $167 \mathrm{~m}$ depth (Hennige et al. 2014, 2015) and used for skeletal + tissue dry weight measurements (Fig. 2). The average skeletal + tissue dry weight of a single coral polyp was found to be $0.78 \pm 0.55 \mathrm{~g}$ (SD), based on a sample size of 192 polyp branches. 
Table 1 ROV video transect information

\begin{tabular}{llllllll}
\hline Dive & $\begin{array}{l}\text { Length } \\
(\mathrm{m})\end{array}$ & $\begin{array}{l}\text { Start } \\
\text { latitude }\left({ }^{\circ} \mathrm{N}\right)\end{array}$ & $\begin{array}{l}\text { Start longitude } \\
\left({ }^{\circ} \mathrm{E}\right)\end{array}$ & $\begin{array}{l}\text { End latitude } \\
\left({ }^{\circ} \mathrm{N}\right)\end{array}$ & $\begin{array}{l}\text { End longitude } \\
\left({ }^{\circ} \mathrm{E}\right)\end{array}$ & $\begin{array}{l}\text { Depth } \\
\text { range }(\mathrm{m})\end{array}$ & $\begin{array}{l}\text { No. images analysed } \\
\text { coral/sponge }\end{array}$ \\
\hline 1 & 185 & 56.826765 & -7.389902 & 56.825257 & -7.391124 & $180-150$ & $20 / 9$ \\
2 & 162 & 56.822525 & -7.395833 & 56.821414 & -7.394715 & $130-113$ & $9 / 62$ \\
3 & 127 & 56.822943 & -7.395204 & 56.823043 & -7.394819 & $138-126$ & $12 / 19$ \\
4 & 25 & 56.822607 & -7.395198 & 56.822587 & -7.395148 & $126-123$ & $1 / 0$ \\
5 & 123 & 56.822801 & -7.394834 & 56.822939 & -7.395057 & $134-128$ & $46 / 5$ \\
8 & 934 & 56.826503 & -7.3701 & 56.821498 & -7.38088 & $170-120$ & $52 / 18$ \\
10 & 86 & 56.822764 & -7.394766 & 56.823019 & -7.394667 & $133-127$ & $21 / 11$ \\
40 & 1341 & 56.821986 & -7.429198 & 56.821622 & -7.402955 & $142-94$ & $1 / 357$ \\
41 & 331 & 56.824581 & -7.392524 & 56.822261 & -7.394078 & $148-129$ & $28 / 49$ \\
\hline
\end{tabular}

Biological data: high-definition video

\section{Step 1}

a. Extract video frames

that contain specimens

of interest such as

corals \& sponges
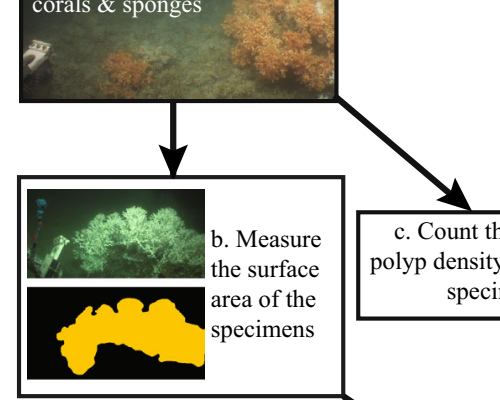

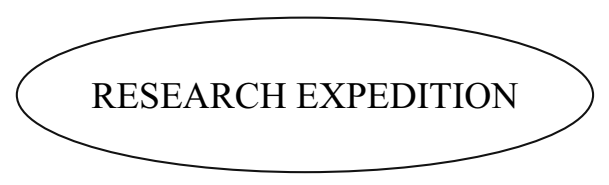

Biological data: collection of specimens

c. Count the average polyp density of the coral specimens

\section{B}

\section{Environmental data}

Ecosystem function data: oxygen consumption and respiration

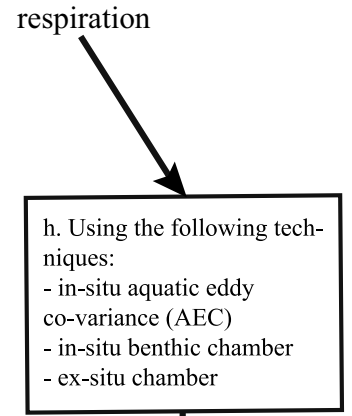

Fig. 2 Graphic overview of the novel methodological approach used in this study

\section{Environmental data}

Bathymetric data were gathered using a Simrad EM2000 ship-mounted multibeam echosounder (MBES), using the RV Lough Foyle, between 28 June and 5 July 2003 (cruise LF26, Roberts et al. 2004). Data were processed to a resolution of $2 \times 2 \mathrm{~m}$. The system has an angular coverage sector of $120^{\circ}, 111$ beams per ping and a $1.5^{\circ}$ beam width across the track. A Seapath 200 GPS system provided realtime heading, altitude, position and velocity solutions (Roberts et al. 2004). Additional multibeam backscatter data were collected in 2012 (cruise JC073) using the shipboard Simrad EM710, with a resolution of $2.5 \times 2.5 \mathrm{~m}$. Physical habitat characteristics were derived 
Table 2 Information on location and time of sample collection together with dry weight biomass, surface area (SA) from the extracted video frames and the calculated SA to dry weight

\begin{tabular}{lllllr}
\hline Specimen & Latitude $\left({ }^{\circ} \mathrm{N}\right)$ & Longitude $\left({ }^{\circ} \mathrm{E}\right)$ & Sponge dry/wet weight $(\mathrm{g})$ & SA from video $\left(\mathrm{m}^{2}\right)$ & Dry weight/SA from video \\
\hline 1 & 56.8231313 & -7.3948795 & $68.40 / 398.25$ & 0.012757 & 5361.97 \\
2 & 56.8231645 & -7.3949222 & $39.98 / 150.68$ & 0.0077039 & 5189.58 \\
3 & 56.8229998 & -7.3950292 & $81.14 / 310.34$ & 0.0174527 & 4649.14 \\
4 & 56.8227665 & -7.394742 & $58.60 / 357.13$ & 0.0149491 & 3919.97 \\
5 & 56.8231588 & -7.3949195 & $18.41 / 68.24$ & 0.001464 & $12,575.14$ \\
6 & 56.822506 & -7.3935978 & $171.30 / 1187.69$ & 0.0241351 & 7097.55 \\
7 & 56.8224958 & -7.3935838 & $167.38 / 1086.40$ & 0.0227044 & 7372.14 \\
\hline
\end{tabular}

conversion value of $S$. coralliophaga. For details on the ratio calculation, see "Biomass estimation" section. from multibeam data including depth, slope, Bathymetric Positioning Index (BPI) (inner and outer radius of 8 and 24 cells respectively, see De Clippele et al. 2017), rugosity $(3 \times 3$ cells $)$ and backscatter using the ArcGIS 10.6.1 software.

\section{Oxygen consumption and respiration data}

In this study, the ex-situ measured $\mathrm{O}_{2}$ consumption of $7.2 \pm 1.2$ (SD) $\mu$ mol $\mathrm{O}_{2}$ skeletal dry weight $\mathrm{g}^{-1} \mathrm{~d}^{-1}$ for live L. pertusa was used as it was collected from the Mingulay Reef Complex (Dodds et al. 2007). In a laboratory, the flow and feeding conditions can be different from the natural environment and can therefore vary (Table 3). However, the value provided by Dodds et al. (2007) was favoured as it is very similar to the in situ measured incubations by Khripounoff et al. (2014) from the submarine canyons of the Bay of Biscay, where the temperature range is similar to that of the MR Complex.

At the MR1, an in situ $\mathrm{O}_{2}$ consumption rate of the community associated with rubble was measured with the non-invasive aquatic eddy co-variance (AEC) technique and provided an average value of $27.8 \mathrm{O}_{2} \pm 2.3$ (SE) mmol m${ }^{-2} \mathrm{~d}^{-1}$ (Rovelli et al. 2015). The respiration rates of $S$. coralliophaga of $47.52 \pm 16.21$ (SD) $\mu \mathrm{mol} \mathrm{CO}_{2}-$ $\mathrm{g}^{-1} \mathrm{~d}^{-1}$ were derived from ex-situ oxygen consumption rate values from chamber incubations by Kazanidis et al. (2018a) (Fig. 2h).

\section{Lophelia reef habitat}

Since our study seeks to better understand the ecological functioning of the biogenic reef habitat L. pertusa provides through its coral framework and rubble, a Lophelia reef habitat map was produced at MR1. This map is based on habitat type data (Lophelia reef habitat vs non-Lophelia reef habitat) (i.e. mud, coarse and fine sediments) from videos from the JC073 and MINCH 2003 expeditions
(Roberts et al. 2005) and the environmental variables detailed in the previous section. The Lophelia reef habitat was produced by creating a composite layer in ArcGIS, which consists of a single raster data set produced from multiple raster bands of environmental data. The rasters used were depth, slope, BPI (inner and outer radius of 8 and 24 cells, respectively, see De Clippele et al. 2017), rugosity $(3 \times 3$ cells $)$ and backscatter. The composite layer was then overlaid with data on habitat type. The "Training Sampler Manager" tool was then used to manually classify the different habitat types with the "polygon delineation" tool. The ArcGIS 10.6.1 Interactive Supervised Classification tool was subsequently used to produce a MR1 Lophelia reef habitat map. One-third of the habitat data set was excluded from the analyses and used to visually assess the accuracy of the habitat map.

\section{Biomass estimation}

Live biomass at MR1 was calculated from HD videos, using a combination of video surface area and coral and sponge dry weight measurements. Data on the skeletal + tissue dry weight of specimens (Hennige et al. 2014; Kazanidis et al. 2016; Kazanidis and Witte 2016) and on methods to estimate coral polyp density (Cathalot et al. 2015) were further compiled from laboratory measurements and the literature. First, the surface area of L. pertusa and $S$. coralliophaga was calculated for each extracted video frame. Based on these measurements, the biomass of live L. pertusa, the skeletal + tissue dry weight of dead $L$. pertusa framework and the biomass of $S$. coralliophaga were calculated. The steps are described in detail in Fig. 2 and in the Online Resource 1. Biomass is here defined as the live tissue of $S$. coralliophaga and L. pertusa. These data were then used to create a predictive biomass map for the Lophelia reef habitat area, using random forest modelling (see "step 4" section). Data extracted from the predictive map could then be used to calculate $\mathrm{C}$ stock and 
Table 3 Overview of L. pertusa oxygen consumption rates available in the literature from the North East Atlantic, normalised for skeletal + tissue dry weight in gram per day. Skeletal + tissue dry

\begin{tabular}{|c|c|c|c|c|c|c|c|}
\hline $\begin{array}{l}\mathrm{O}_{2} \text { consumption } \\
\text { rate }\left(\mu \mathrm{mol} \mathrm{O}_{2}\right. \\
\left.\mathrm{g}^{-1} \mathrm{~d}^{-1}\right)\end{array}$ & $\begin{array}{l}\text { Location of } \\
\text { measurement }\end{array}$ & Collection site & $\begin{array}{l}\text { Depth } \\
\text { (m) }\end{array}$ & $\begin{array}{l}\text { In situ } \\
\text { temperature } \\
\left({ }^{\circ} \mathrm{C}\right)\end{array}$ & $\begin{array}{l}\text { Aquarium } \\
\text { temperature } \\
\left({ }^{\circ} \mathrm{C}\right)\end{array}$ & $\begin{array}{l}\text { Acclimatisation } \\
\text { time }\end{array}$ & Publication \\
\hline 7.2 & Ex-situ & Mingulay Reef & 130 & $9.5-10.5$ & 9 & 2-7 days & Dodds et al. (2007) \\
\hline 6.48 & Ex-situ & Tisler Reef & $70-155$ & $6-9$ & 8 & 57 days & Larsson et al. (2013a) \\
\hline $2.88-6$ & Ex-situ & Tisler Reef & $95-110$ & $6-9$ & 8 & 1 month & Larsson et al. (2013b) \\
\hline 34.32 & Ex-situ & Mingulay Reef & $141-167$ & $9.5-10.5$ & 10 & 2 days & Hennige et al. (2014) \\
\hline 7.3 & In situ & Bay of Biscay & 850 & $9.6-10.2$ & NA & NA & Khripounoff et al. (2014) \\
\hline 15.8 & Ex-situ & Bay of Biscay & 850 & $9.6-10.2$ & 10 & $1 \mathrm{~h}$ & Khripounoff et al. (2014) \\
\hline 25.1 & Ex-situ & Mediterranean & 300 & $12-14$ & $11-13.5$ & 9 months & Naumann et al. (2014) \\
\hline $4.8-6$ & Ex-situ & Mingulay Reef & $141-167$ & $9.5-10.5$ & $9-12$ & 7 days & Hennige et al. (2015) \\
\hline $4.8-6$ & Ex-situ & Mingulay Reef & $141-167$ & $9.5-10.5$ & $9-12$ & 7 days & Hennige et al. (2015) \\
\hline $1.2-4.8$ & Ex-situ & Mingulay Reef & $141-167$ & $9.5-10.5$ & $9-12$ & 7 days & Hennige et al. (2015) \\
\hline $1.2-4.32$ & Ex-situ & Tautra Reef & 50 & 7.5 & 7.5 & 3 weeks & Baussant et al. (2017 \\
\hline 6.39 & Ex-situ & Rockall Bank & $500-1000$ & $7-9$ & $8-10$ & $2 \mathrm{~h}$ & de Froe et al. (2019) \\
\hline $1.68-7.2$ & Ex-situ & Nakken Reef & $200-219$ & $7-7$ & 8 & 13 days & Maier et al. (2019) \\
\hline $4.8-12$ & Ex-situ & Nakken Reef & $200-220$ & $7-8$ & 8 & 0 & Maier et al. (2020) \\
\hline
\end{tabular}

weight is reported here, as this unit is the most commonly chosen one to calculate $\mathrm{O}_{2}$ consumption of $L$. pertusa 
the white and orange live branches. By following Vad et al. (2017), it was possible to estimate the dead skeletal mass from live skeletal mass assuming that at least $73 \%$ of $L$. pertusa colonies are composed of dead coral framework. The value $73 \%$ is the minimum proportion of dead skeleton in the L. pertusa colonies and was chosen here as advised by $\mathrm{Vad}$ et al. 2017. The average proportion is $0.82 \% \pm 0.05(\mathrm{SD})$. Windholz et al. 1983 found a ratio of 0.12 between the mass of $\mathrm{CaCO}_{3}$ and mass of inorganic $\mathrm{C}$. The skeletal mass of $L$. pertusa framework (Fig. 2c-e) equalling $\mathrm{CaCO}_{3}$ mass, the amount of inorganic $\mathrm{C}$ stores was therefore calculated by multiplying the $\mathrm{CaCO}_{3}$ mass by 0.12 . For non-calcifying organisms (e.g. sponges, anthozoans, tunicates), it is estimated that the average $\mathrm{C}$ content amounts to $18 \% \pm 3.47$ (SD) (Kazanidis and Witte 2016; Kazanidis et al. 2018a, b). This value was used to calculate C stock of $S$. coralliophaga from its dry weight measurements (Kazanidis and Witte 2016; Kazanidis et al. $2018 a, b$ a,b).

\section{Predictive mapping}

Step 4

Based on video frame data points (Fig. 2e) and environmental variables (i.e. depth, BPI, slope, backscatter, rugosity) (Fig. 2f), a predictive biomass map was created using a random forest approach (Fig. $2 \mathrm{~g}$ ) with the random forest package in R (Breiman 2001). Correlated environmental variables $(>0.5)$ were removed prior to analyses. The random forest algorithm fits multiple decision trees to a training data set using randomly selected subsets of the predictor variables. Here, the training data set contained one-third of the total data points. To improve the prediction, randomly selected coral and sponge biomass absence data points were added to the data set from the JC073 and MINCH 2003 expeditions (De Clippele et al. 2017).

The importance of the environmental variables was assessed by plotting the mean decrease in accuracy for each variable to indicate their contribution to the model's performance. Based on Rowden et al. (2017), we used a bootstrap technique to produce estimates of model uncertainty. In a process repeated 100 times, a random sample of the data was drawn with replacement each time and a model equal to the original constructed. Predictions were then made, resulting in 100 estimates from which the coefficient of variation (CV) was calculated to examine the output stability, giving a range the random forest model output might vary. This is measured as the standard deviation/mean $\times 100$ (Wei et al. 2010).

\section{Carbon turnover}

Step 5

From the predictive Lophelia reef biomass map (see step 4 section), the total amount of biomass was extracted. This is used to calculate the yearly $\mathrm{C}$ turnover from $\mathrm{O}_{2}$ consumption and respiration measurements, assuming a $1: 1 \mathrm{C}$ to $\mathrm{O}_{2}$ ratio (Glud 2008). Shifts in the $\mathrm{O}_{2} / \mathrm{CO}_{2}$ ratio over time, as well as spatially, have been widely documented in tropical coral reef habitats and other benthic marine ecosystems (Therkildsen and Lomstein 1993; Glud 2008; Takeshita et al. 2018; Bolden et al. 2019). Although the discussion of such dynamics for deep-sea CWC reefs settings goes behind the remit of this study, it should be noted that shifts in the $\mathrm{O}_{2} / \mathrm{CO}_{2}$ ratio would proportionally offset our conservative estimates of the yearly $\mathrm{C}$ turnover rate by the reef. Carbon turnover is here defined as the conversion of ingested food into biomass and loss by respiration (Fig. 2i). Since the community associated with the coral rubble is similar to the community associated to dead exposed coral framework (Kazanidis et al. 2016), it was assumed that the respiration rate of the community associated with coral rubble and the dead coral framework is the same at the MR1. Gross activity such as biomass build up followed by subsequent degradation was not accounted for this study. However, in deep-sea settings net rates will be very close to the gross rates (Glud 2008). From an ecosystem-wide budget assessment, it is the net rates that are relevant for evaluating the overall importance of coldwater coral reefs in oceanic $\mathrm{C}$ budgets and were therefore used here.

\section{Results}

\section{Predictive maps}

The ArcGIS Interactive Supervised Classification procedure resulted in a Lophelia reef map covering an area $1.7 \mathrm{~km}^{2}$ (Fig. 3). From the results in "Stock and turn-over of carbon" section, it was calculated that live and dead $L$. pertusa framework cover $0.3 \mathrm{~km}^{2}, S$. coralliophaga covers $0.009 \mathrm{~km}^{2}$ resulting in $L$. pertusa derived rubble covering a total of $1.3 \mathrm{~km}^{2}$ of the Lophelia reef habitat.

The live L. pertusa biomass random forest model, based on the mean biomass input data, explained $16.8 \%$ of the variation in data. The random forest models based on the minimum and maximum biomass input data can be found in the Online Resource 2. The environmental variables that contributed most to explaining the spatial variability in the amount of live coral biomass were rugosity, depth and slope (Fig. 4). The L. pertusa predictive biomass map 
(Fig. 5) illustrated that the highest biomass is mostly located on the eastern ridge of MR1, with hotspots of biomass visible on the minimounds. The predictive maps indicate a total mean skeletal mass of $1046 \mathrm{~T}$ (range 137-2525 T skeletal mass) and live L. pertusa mean biomass of $209 \mathrm{~T}$ (range 26-515 $\mathrm{T}$ biomass). This was converted to a mean of $2828 \mathrm{~T}$ of dead exposed coral skeleton framework (range 370-6827 T skeletal mass) (see Methodology step 2, Table 4). The CV map provided an indication for the possible range where this random forest prediction might vary (Fig. 6). The CV map indicates a high uncertainty on the south-western part of the reef where video data are missing.

The $S$. coralliophaga biomass random forest model explained $5.88 \%$ of the variation in biomass. The environmental variables that contributed most to explaining the spatial variability in the sponge biomass were rugosity and slope (Fig. 4). The S. coralliophaga predictive map (Fig. 7) showed the highest biomass on the eastern ridge of MR1. The CV map gives an indication for the possible range where this random forest prediction might vary (Fig. 8). The CV map indicates a high uncertainty on the north-eastern part of the reef where video data are missing.

The results of the minimum and maximum (range) of biomass of L. pertusa and S. coralliophaga random forest models can be found in Online Resource 2.

\section{Stock and turnover of carbon}

A total mean of $126 \mathrm{~T} \mathrm{C} \mathrm{(range} \mathrm{16-303} \mathrm{T} \mathrm{C)} \mathrm{and} 339 \mathrm{~T} \mathrm{C}$ (range 44-819 T C) was calculated to be stored within the live and dead L. pertusa framework, respectively, for the total Lophelia reef habitat area of $1.7 \mathrm{~km}^{2}$. These values largely exceeded the mean $\mathrm{C}$ stock of $10 \mathrm{~T}$ (range 5-18 T C) of S. coralliophaga, reaching a total mean of $475 \mathrm{~T} \mathrm{C}$ (range 65-1140 T C). The average live mass (skeletal weight + biomass) of a $L$. pertusa colony is $0.74 \mathrm{~kg} \mathrm{~m}^{-2}$ (range $0.09-1.66 \mathrm{~kg} \mathrm{~m}^{-2}$ ) with the average dead skeletal weight of $L$. pertusa colony being $1.6 \mathrm{~kg} \mathrm{~m}^{-2}$ (range $0.2-4 \mathrm{~kg} \mathrm{~m}^{-2}$ ). The average biomass of $S$. coralliophaga is $213 \mathrm{~g} \mathrm{~m}^{-2}$ (range $118-308 \mathrm{~g} \mathrm{~m}^{-2}$ ). The community associated (e.g. anthozoans, ophiuroids, sponges) with rubble was responsible for the largest turnover of organic material, reaching an annual rate of $163 \mathrm{~T} \mathrm{yr}^{-1}$ (range 149-176 T C $\mathrm{yr}^{-1}$ ) (Table 4, Fig. 9). The community associated with dead L. pertusa framework and live L. pertusa was

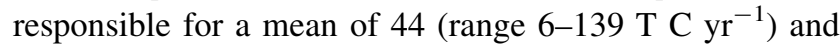
$32 \mathrm{~T} \mathrm{yr}^{-1}$ (range 4-93 $\mathrm{T} \mathrm{C} \mathrm{yr}^{-1}$ ) of $\mathrm{C}$ mineralisation, respectively (Table 4, Fig. 9). The sponge $S$. coralliophaga only contributed $1 \mathrm{~T} \mathrm{C} \mathrm{yr}^{-1}$ (range 1-2 $\mathrm{T} \mathrm{C} \mathrm{yr}^{-1}$ ). This resulted in a total $\mathrm{C}$ turnover of the Lophelia reef area with a mean of $241 \mathrm{~T} \mathrm{C} \mathrm{year}^{-1}$ (range $160-400 \mathrm{~T} \mathrm{yr}^{-1}$ ), corresponding to an $\mathrm{O}_{2}$ consumption of $32.37 \mathrm{mmol} \mathrm{m}^{-2} \mathrm{~d}^{-1}$ (range $21.48-53.72 \mathrm{mmol} \mathrm{O}_{2} \mathrm{~m}^{-2} \mathrm{~d}^{-1}$ ). If the Lophelia reef area was to consist entirely of soft-sediments, for which depth-based turnover rates of oxygen/carbon are available in the literature (see Glud 2008), than the area
Fig. 3 Lophelia reef habitat predicted using the ArcGIS Interactive Supervised Classification

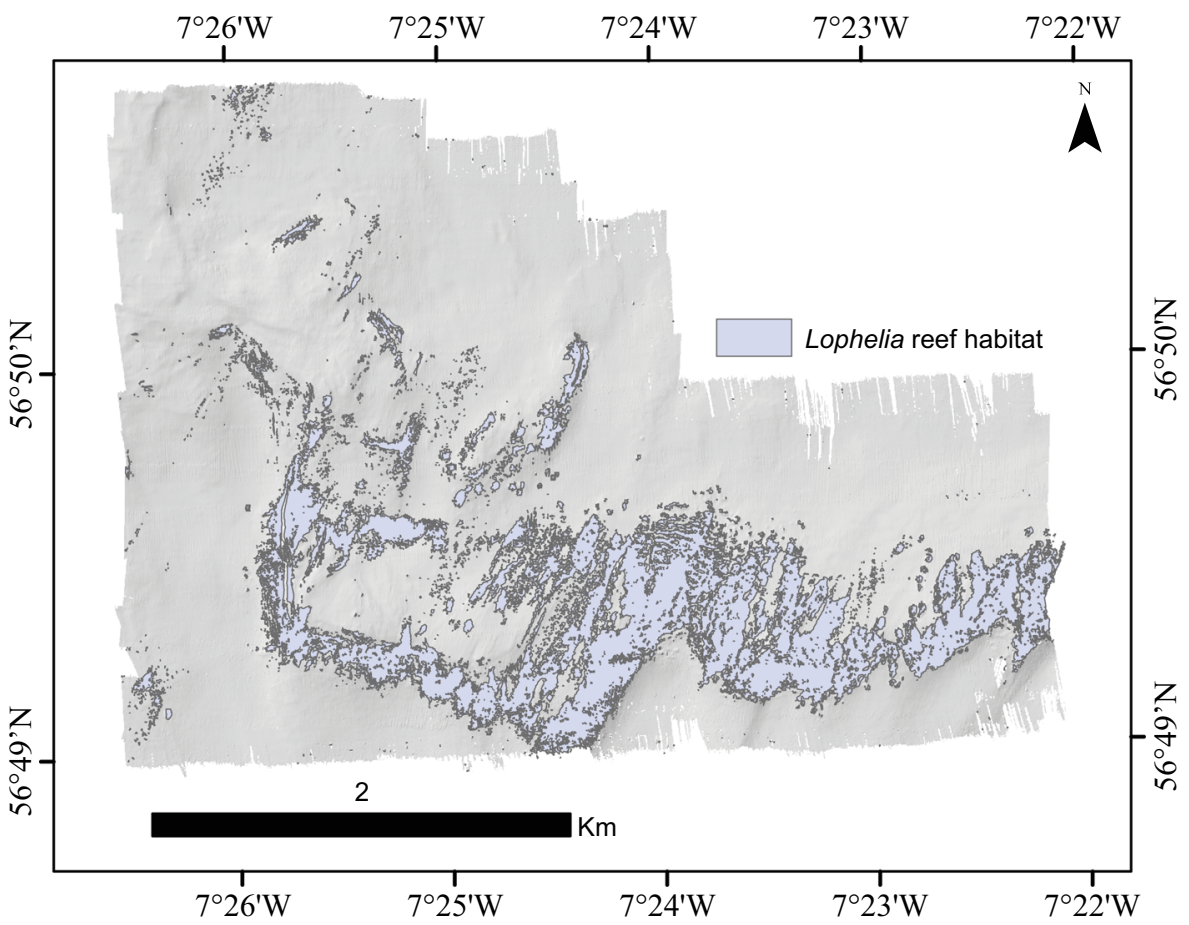


Fig. 4 Mean decrease in accuracy plots of the mean Lophelia pertusa and Spongosorites coralliophaga random forest model indicating what the contribution of each variable is to the model performance. When the mean decrease accuracy value is higher for a certain variable, the removal of this variable from the model will decrease the model's performance

Fig. 5 Modelled amount of the mean biomass of live Lophelia pertusa in the Lophelia reef habitat area of the Mingulay reef
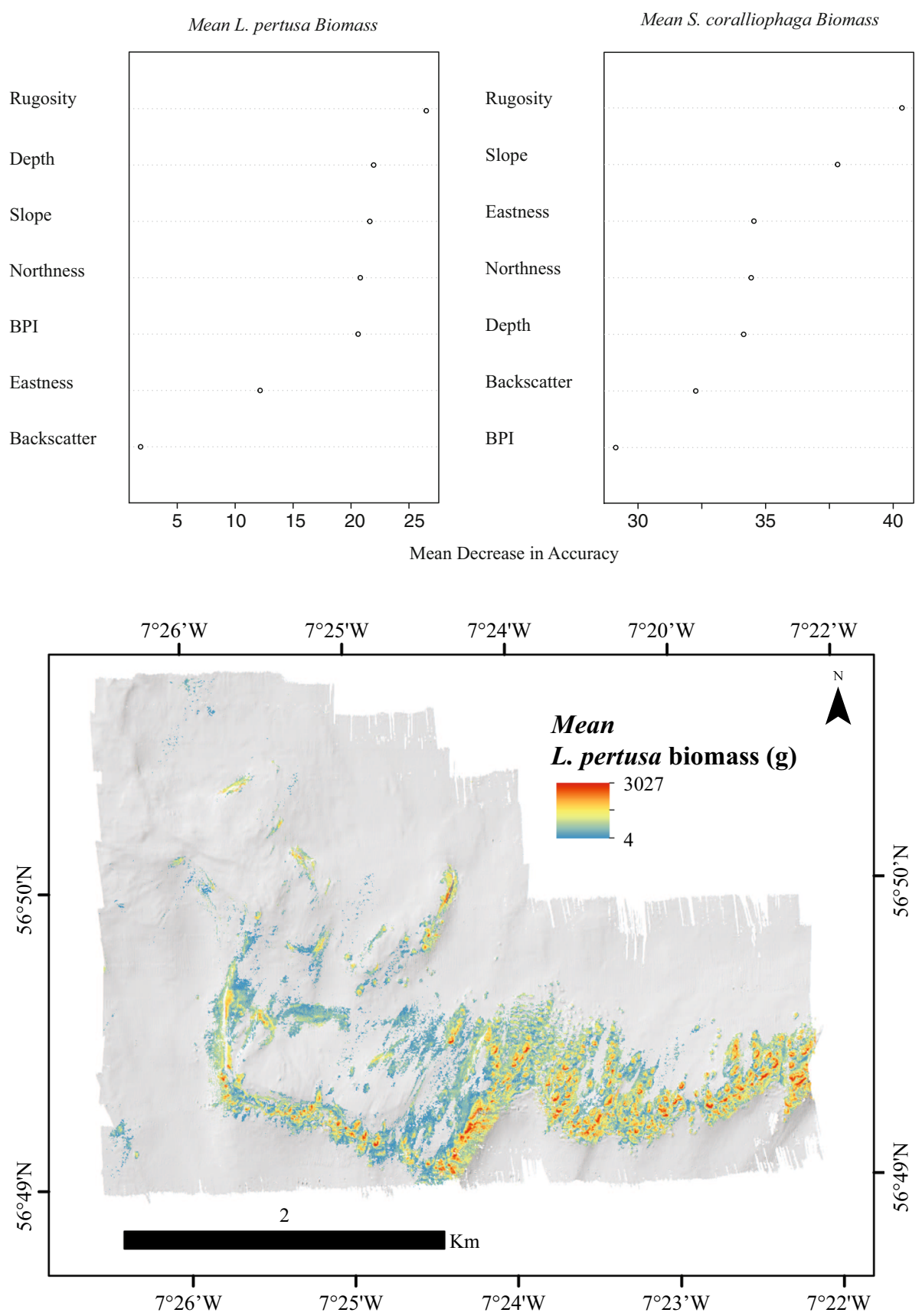

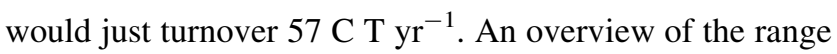
of the Lophelia reef habitat predicted absolute minimum and maximum dry, wet weight and carbon (C) stock masses, together with the mass of oxygen $\left(\mathrm{O}_{2}\right)$ and $\mathrm{C}$ turned over are given in Table 4.

\section{Discussion}

This study developed a new methodology, to successfully map and estimate cold-water coral reef biomass and from that to make the first extrapolations of reef-scale $\mathrm{C}$ turnover and standing stock. These calculations were performed for one of the best-studied CWC reefs in the world and provide a much needed baseline assessment at a time of rapid climatic change when marine food webs are predicted to undergo rapid transitions. In addition, such biomass maps can guide sampling and monitoring expeditions, help 
Table 4 Overview of the range Lophelia reef habitat predicted absolute minimum, mean and maximum dry, wet weight and carbon (C) stock masses, together with the mass of oxygen $\left(\mathrm{O}_{2}\right)$ and $\mathrm{C}$ turned over

\begin{tabular}{|c|c|c|c|c|c|c|}
\hline & & L. pertusa live framework & L. pertusa dead framework & S. coralliophaga & Coral rubble & Total \\
\hline \multirow[t]{3}{*}{ Dry weight/skeletal mass $(\mathrm{T})$} & Min & 137 & 370 & 32 & UN & $>539$ \\
\hline & Mean & 1046 & 2828 & 58 & UN & $>3932$ \\
\hline & Max & 2525 & 6,827 & 84 & UN & $>9436$ \\
\hline \multirow[t]{3}{*}{ Wet weight biomass $(\mathrm{T})$} & Min & 26 & NA & 168 & UN & $>194$ \\
\hline & Mean & 209 & NA & 304 & UN & $>513$ \\
\hline & Max & 515 & NA & 440 & UN & $>955$ \\
\hline \multirow[t]{3}{*}{$\mathrm{C}$ stock $(\mathrm{T})$} & Min & 16 & 44 & 5 & UN & $>76$ \\
\hline & Mean & 126 & 339 & 10 & UN & $>475$ \\
\hline & Max & 303 & 819 & 18 & UN & $>1164$ \\
\hline \multirow[t]{3}{*}{$\mathrm{O}_{2}\left(\mathrm{~T}_{\text {year }}{ }^{-1}\right)$} & Min & 10 & 15 & 3 & 398 & 426 \\
\hline & Mean & 85 & 118 & 3 & 435 & 641 \\
\hline & Max & 248 & 345 & 6 & 470 & 1069 \\
\hline \multirow[t]{3}{*}{ C $\left(\mathrm{T}_{\text {year }}{ }^{-1}\right)$} & Min & 4 & 6 & 1 & 149 & 160 \\
\hline & Mean & 32 & 44 & 1 & 163 & 241 \\
\hline & Max & 93 & 139 & 2 & 176 & 400 \\
\hline
\end{tabular}

NA Not Applicable, UN Unknown

For L. pertusa, the uncertainty of the number of the counted polyps per $\mathrm{m}^{2}$, a polyp's weight and the oxygen consumption rate were included. For $S$. coralliophaga, the uncertainty of the conversion from surface area to mass, the oxygen consumption rate and the percentage $\mathrm{C}$ stock were included in the calculation. For coral rubble, the uncertainty of the oxygen consumption rate was included in the calculation

Fig. 6 The coefficient of variation computed as the standard deviation/mean $\times 100$ for the random forest model of the mean biomass of $L$. pertusa in the Lophelia reef habitat area of the Mingulay reef

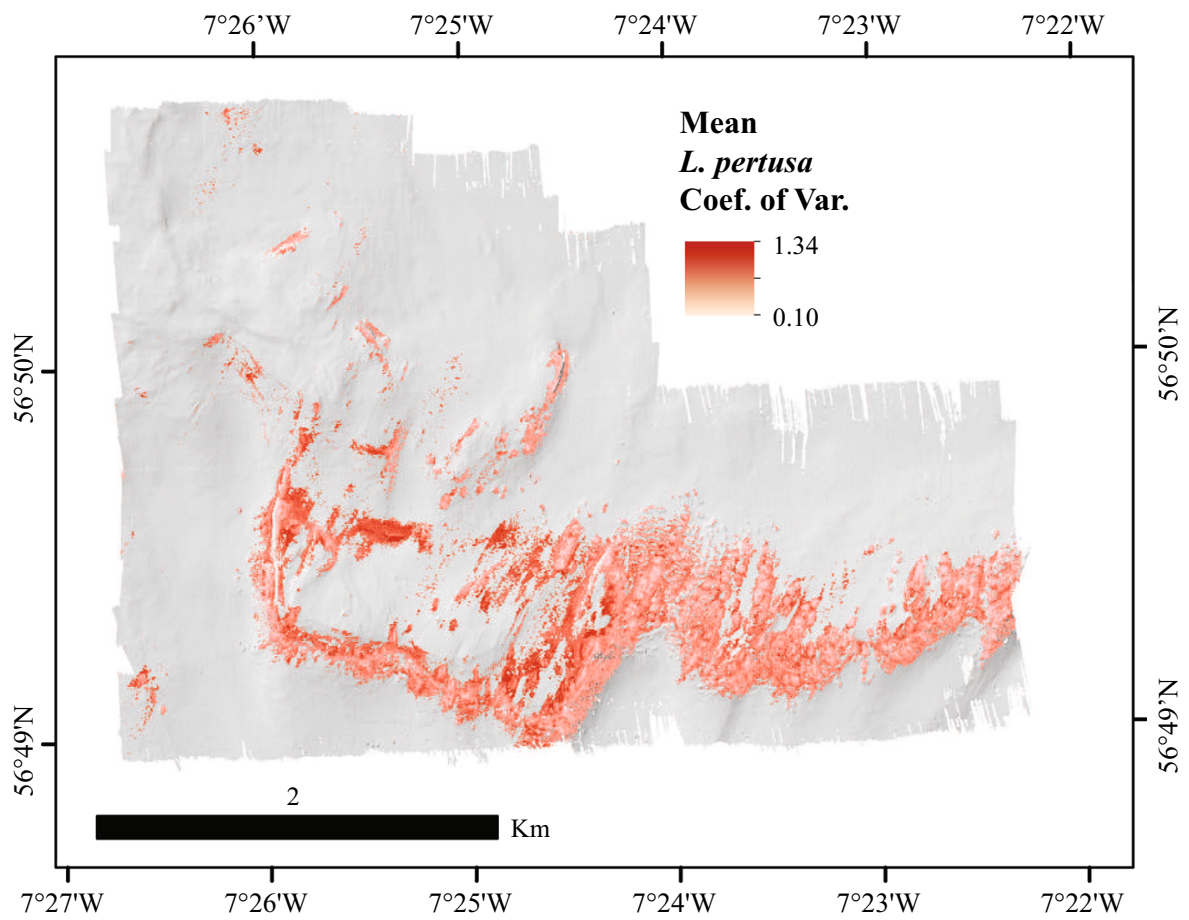

identify areas that should be protected from human activities and even potentially predict areas that could have marine biotechnological potential. Furthermore, this work advances our nascent knowledge of C storage in CWC habitats and the significance of their secondary productivity, one of the criteria used to define ecologically or biologically significant areas (EBSAs) (Burrows et al. 2014; Titschack et al. 2015; Johnson et al. 2018).

This study further emphasises the importance of CWC reefs as hotspots for benthic mineralisation (Cathalot et al. 
Fig. 7 Modelled amount of the mean biomass of Spongosorites coralliophaga in the Lophelia reef habitat area of the

Mingulay reef
Fig. 8 The coefficient of variation computed as the standard deviation/mean $\times 100$ for the random forest model of the mean biomass of $S$. coralliophaga in the Lophelia reef habitat area of the Mingulay reef
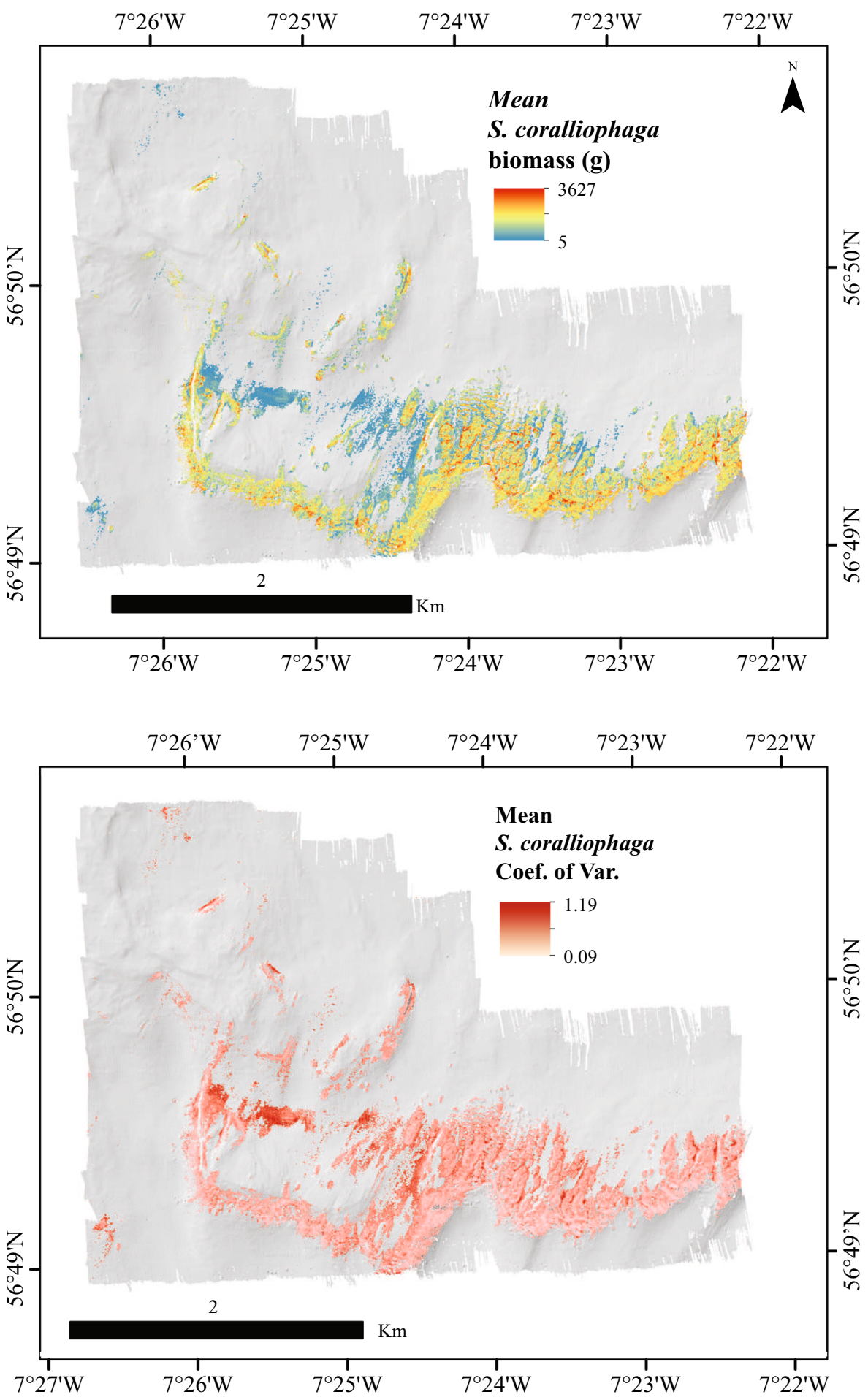

2015; Rovelli et al. 2015). Carbon turnover at the MR1 was found to be three to seven (with a mean of four) times higher than the global average for soft-sediment at the same depth (Glud 2008). By taking the spatial heterogeneity of $L$. pertusa and $S$. coralliophaga into account, the mean amount of oxygen consumption found here (32.37 mmol m-2 $\mathrm{d}^{-1}$ ) was estimated to be slightly higher than Rovelli et al.'s (2015) finding at MR1 (27.8 mmol m $\left.\mathrm{m}^{-2} \mathrm{~d}^{-1}\right)$. However, the value reported here falls within the range that de Froe et al. (2019) found for CWC communities at the deeper Logachev Mounds and that White et al. (2012) found at the shallower Tisler Reef. While complex to undertake, the AEC technique has many merits since it measures community oxygen consumption, 
Carbon provided by Primary Productivity:

294 T Carbon per year

SEA SURFACE

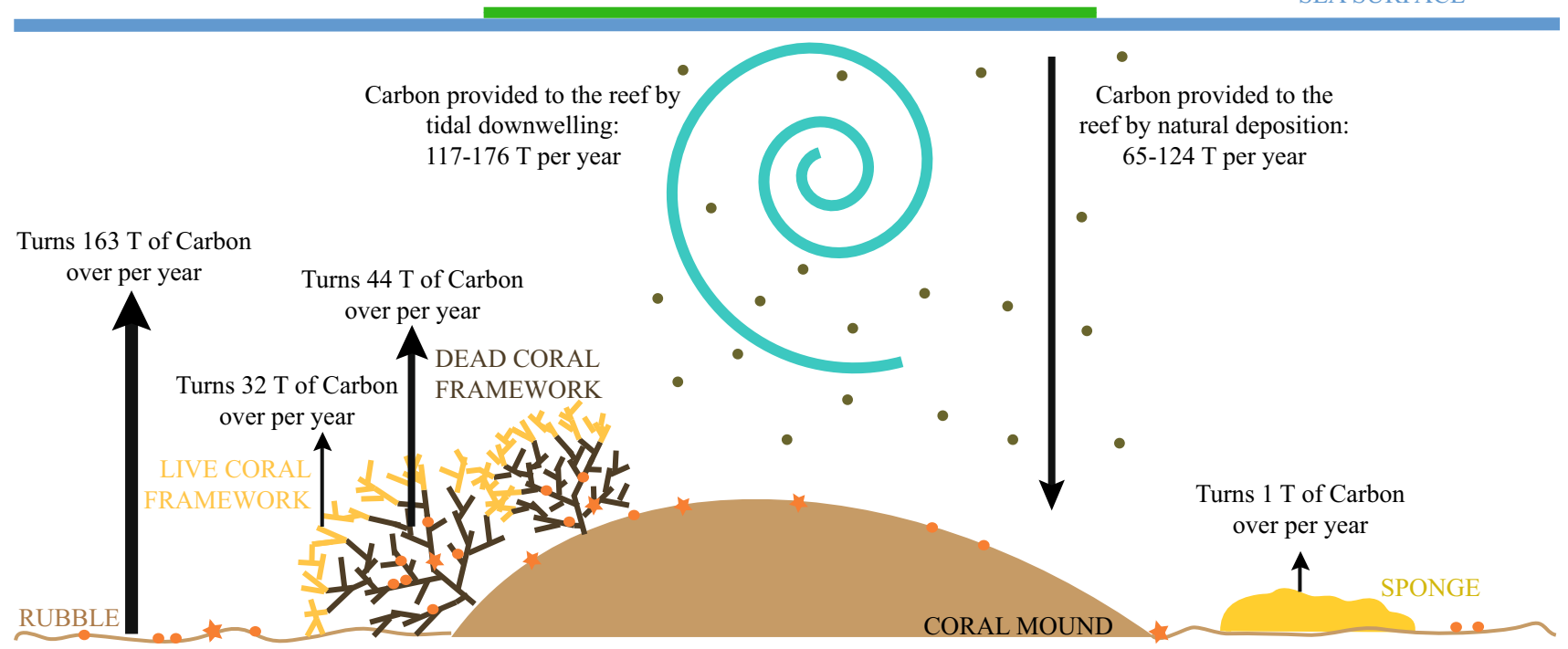

Fig. 9 Diagram representing the Mingulay cold-water coral reef, the mean amount $L$. pertusa rubble, live and dead framework and the yellow encrusting sponge $S$. coralliophaga contribute to the carbon turnover. The orange circles and stars represent the fauna (including dense Parazoanthus sp. and ophiuroids) and microbes associated with the rubble and dead coral framework. The dark green circles represent the organic matter that is transported from the surface water to the

thereby inherently accounting for the complex and highly variable benthic activity associated with biogenic reef communities (Cathalot et al. 2015; de Froe et al. 2019; Rovelli et al. 2015). However, the size of an AEC footprint (i.e. the area of the benthic habitat integrated within the AEC flux measurements) varies with local conditions such as bottom roughness and deployment strategies (i.e. measurement height above the reef). For example, at Mingulay, the estimated AEC footprint size was $15 \mathrm{~m}^{2}$, while at the Logachev Mound Province, it was estimated to be $500 \mathrm{~m}^{2}$ (Rovelli et al. 2015; de Froe et al. 2019). The Mingulay AEC site was dominated by rubble, with little to no biomass of S. coralliophaga and live L. pertusa (see Fig. 1c in Rovelli et al. 2015). If the $\mathrm{O}_{2}$ consumption value from the AEC technique at the rubble-dominated site was to be considered alone, the annual organic $\mathrm{C}$ turnover of the reef would be as low as $204 \mathrm{~T} \mathrm{C} \mathrm{yr}^{-1}$. In our case, the colonies of L. pertusa and S. coralliophaga were under-represented under the AEC footprint, and their inclusion in this study

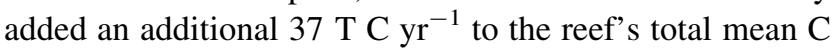
turnover. This demonstrates that accounting for the heterogeneity of biomass can help to (a) improve the assessment of the role a CWC reef plays in the regional $\mathrm{C}$ cycling; (b) ground truth the upscaling of AEC measurements and (c) help place AEC instrumentation, strategically targeting locations that best represent average reef. The thickness of the upward facing arrows indicates the relative importance of the contribution of the coral habitats and the sponge mean annual carbon turnover. The diagram also shows an estimate of the amount of primary production above the reef and the contribution of two supply pathways to the reef, natural deposition and tidal downwelling. The given range refers to the deeper and shallower area of the reef, respectively

community compositions or locations dominated by a specific community.

While this study provides a novel approach to mapping biomass using data derived from HD videos, the resulted C turnover budget is affected by the uncertainties propagated across all of the measurements and assumptions present in each of the five steps (Table 4). The ability of automated underwater vehicles (AUVs) to collect more continuous photographic seafloor maps (Bodenmann and Thornton 2017; Thornton et al. 2016) has the potential to provide a more accurate method to convert surface area measurements to biomass. In addition, an increase in the availability of oxygen consumption and respiration rates could also affect the accuracy of the output values. For example, $S$. coralliophaga is typically covered by a species-rich community of sessile fauna (Kazanidis et al. 2016), which could not be included in the respiration rate measurements due to technical restrictions (i.e. the size of the respiration chambers available). The sponge's biomass, however, accounts for $\sim 90 \%$ (or more) of the total sponge plus epifauna biomass; therefore, $\mathrm{a} \sim 10 \%$ increase to the total respiration should be considered but remains to be confirmed. Also, this study assumed that the contribution to the $\mathrm{C}$ turnover of bacteria, infauna and epifauna growing on rubble and dead coral framework is equal, however, in reality, they might be different (Rowe et al. 1997; van Oevelen et al. 2009). It is also important to note that only a 
small proportion of the predictive models (5.88\% for $S$. coralliophaga and $16.8 \%$ for L. pertusa) is explained by the environmental variables that we were able to take into account. The prediction will be improved with more relevant and higher resolution variables. It is an imperative to obtain such variables to produce predictive maps, especially if there is a clear relationship between biomass and particulate organic carbon (POC), for example. These considerations highlight that with more respiration and environmental data becoming available, $\mathrm{C}$ budgets will be further refined and improved (Stratmann et al. 2019).

Our calculations suggest that communities associated with dead coral branches (rubble and dead coral framework) contribute 79-97\% (average $85 \%$ ) of the total benthic $\mathrm{C}$ turnover at the MR1. Our estimate is slightly higher than the estimates from the deeper (500-800 m) cold-water coral carbonate mounds at the Logachev Mound Province (LMP) where dead framework has been estimated to contribute between 10 and $75 \%$ of the total benthic $\mathrm{C}$ turnover (de Froe et al. 2019). This range was calculated based on six box cores, sampled from two mounds, for which the dry weight of dead and live coral framework was calculated per square metre (de Froe et al. 2019).

There was 27 times more dead than living coral framework at the LMP, whereas at MR1, there was only three times more dead than living coral framework. Since dead coral framework $\mathrm{C}$ turnover is estimated to be 30 times lower than that of live coral framework (de Froe et al. 2019), the far higher proportion of live coral reef at MR1 likely explains the higher proportion of $\mathrm{C}$ turnover ascribed to live coral reef at MR1.

Furthermore, it is important to note that MR1 is located at much shallower depths where surface productivity is tightly coupled to the benthos through tidal downwelling (Davies et al. 2009), further explaining the high total C turnover compared to the LMP. This is also supported by the findings of Kazanidis et al. (2016), who found that $S$. coralliophaga at the MR1 hosted a much higher epifaunal biomass compared to $S$. coralliophaga found in the LMP.

In addition, there are gross differences in Lophelia pertusa colony morphology between LMP and MR1 (e.g. Vad et al. 2017; De Clippele et al. 2019b). Cold-water coral colony morphology is influenced by many interacting actors including settlement substrate stability and colony growth space constraints (Zibrowius 1980, 1984), local hydrodynamics, competition for food and space (Freiwald et al. 1997; De Clippele et al. 2018) and the presence of the non-obligate symbiotic polychaete Eunice norvegica (Linnaeus 1767) (Freiwald and Wilson 1998, Roberts 2005). Given the differences in depth, hydrodynamics and food supply between the two sites, we also see differences in skeletal thickening and polyp density. Indeed, visual observations indicate that the corals at the MRC have far more slender and denser packing of polyps compared to colonies at the LMP (Vad et al. 2017; De Clippele et al. $2019 b$ ). However, to quantify these differences, there is a need to measure the contribution of live and dead framework within and between sites to the total benthic $\mathrm{C}$ turnover. This is especially important in relation to some deeper reefs, where ocean acidification threatens to dissolve dead coral framework of which the majority of some CWC reefs consist (Hennige et al. 2015). Interestingly, sponges generally do not seem to be affected much by ocean acidification, suggesting that they might have a competitive advantage (Bell et al. 2018). However, the dominant growing substrate for $S$. coralliophaga could decrease owing to the dissolution of dead coral framework. The resil

ience to the effects of ocean warming appears to be species specific. For sponges, both positive and adverse effects have been listed in the literature (e.g. Bell et al. 2018; Stevenson et al. 2020). For L. pertusa, an increase in metabolic rate has been found when increasing seawater temperatures (Dodds et al. 2007). However, climate change-driven increases in ocean temperatures can cause secondary physical changes in the water column such as stratification and changes in the mixed layer depth resulting in lower nutrients and net primary production. A reduced or altered food supply, especially in combination with an increased metabolism could cause the benthic fauna to starve (Sweetman et al. 2017; Lesser and Slattery 2020).

One of the advantages of estimating the annual amount of $\mathrm{C}$ turnover is that one can quantify the importance of the different $C$ supply pathways (e.g. by natural deposition and tidal downwelling) of $\mathrm{C}$ from surface water primary productivity (PP) to the reef. An average primary productivity in the water column above the MR1 of $0.048043 \mathrm{~g} \mathrm{~m}^{-3}$ day $^{-1}$ can be calculated using an open-source marine data layer on mean PP from the Bio-Oracle website (Tyberghein et al. 2012; Assis et al. 2018). This equals to a yearly PP above the Lophelia reef habitat of $294 \mathrm{~T} \mathrm{C} \mathrm{year}^{-1}$ (Fig. 9), a value that is broadly similar to the here estimated area's mean C turnover by the CWC community (241 T C year ${ }^{-1}$ ). Using the parametrization by Suess (1980), the amount of $\mathrm{C}$ reaching the seafloor from the sea surface via natural deposition was estimated to be 65-124 $\mathrm{T} \mathrm{C}$ year ${ }^{-1}$, calculated for the shallowest $(91 \mathrm{~m})$ and deepest point (180 m) of Lophelia reef habitat area. To sustain the annual reefs' mean $\mathrm{C}$ turnover rate reported in this study, an additional 117-176 $\mathrm{T} \mathrm{C}_{\mathrm{C}}$ year $^{-1}$ (49-73\% of the reef turnover) would have to be supplied through tidal downwelling and/or deep-water advection (see Fig. 9). When considering the calculated range in the reef turnover rate, an additional minimum 36-95 $\mathrm{T} \mathrm{C}$ year $^{-1}$ (23-59\% of the reef turnover) or maximum 276-335 $\mathrm{T} \mathrm{C}$ year $^{-1}$ (69-84\% of the reef turnover) would have to be supplied to the reef 
through tidal downwelling and/or deep-water advection. The estimated maximum amount of $\mathrm{C}$ supplied from PP through natural deposition $\left(124 \mathrm{~T} \mathrm{C} \mathrm{year}^{-1}\right)$ is close to the minimum amount of $\mathrm{C}$ reef turnover $\left(160 \mathrm{~T} \mathrm{C}^{\mathrm{y}}\right.$ year $\left.^{-1}\right)$. This illustrates that monitoring and/or managing surface PP would be a key consideration for any conservation efforts of this CWC reef ecosystem. Isotopical analyses $\left(\delta^{13} \mathrm{C}\right.$, $\delta^{15} \mathrm{~N}$ ) of sponge and coral tissue samples from the MR support this finding, since they indicate $L$. pertusa, $S$. coralliophaga and associated benthic macrofauna primarily feed on fresh algal matter vertically transported from the water surface rather than on decayed organic matter being laterally advected (Duineveld et al. 2012; Kazanidis and Witte 2016). The lipid signature of L. pertusa at the MR also indicates an input of lipid-rich prey species (i.e. zooplankton prey) and a strong link to surface production (Dodds et al. 2009). Both the quality and the quantity of food resources have an essential role in the functioning of the coral reef (Duineveld et al. 2012), therefore changes in $\mathrm{C}$ supply processes and primary production could have a strong impact on the functioning of the reef.

Lastly, this study demonstrates the value of combining regional acoustic mapping, high-resolution video imagery and AEC measurements, allowing radically improved assessments of the dynamics and functioning of CWC communities. Automating surface area measurements from imagery using machine learning techniques and developing 3D visual imaging technology for seafloor mapping will provide new and more efficient pathways to assess deepsea biomass and its contribution to the $\mathrm{C}$ cycle (Elawady 2015; Thornton et al. 2016; Bodenmann and Thornton 2017; Conti et al. 2019). The methodology developed here has the potential to be applied to other underwater habitats. By closing these significant gaps in our current knowledge on biomass and cold-water coral reef $\mathrm{C}$ turnover, we can increase the capacity to understand anthropogenic and climate change pressures and ensure the long-term health and resilience of these ecosystems.

Acknowledgements The ROV video and multibeam bathymetry used in this study were gathered during the JC073 expedition through the UK Ocean Acidification Research Programme benthic consortium (NERC Grant NE/H017305/1 to JMR). We thank the captain and the crew of the RRS James Cook for assistance at sea. We would also like to thank Megan Winstanley-Ramos and Ammaarah Sharif for assisting with the image data collection. The authors would like to acknowledge with thanks the two reviewers for their very helpful comments. LDC, GK, JV, JMR acknowledge funding from the EU Horizon 2020 ATLAS (Grant Agreement No. 678760 to JMR) and iAtlantic projects (Grant Agreement No. 818123 to JMR). RG received support both through ATLAS and through HADES-ERC (Project ID 669947). This manuscript reflects the authors' view alone, and the European Union cannot be held responsible for any use that may be made of the information contained herein. On behalf of all authors, the corresponding author states that there is no conflict of interest.
Open Access This article is licensed under a Creative Commons Attribution 4.0 International License, which permits use, sharing, adaptation, distribution and reproduction in any medium or format, as long as you give appropriate credit to the original author(s) and the source, provide a link to the Creative Commons licence, and indicate if changes were made. The images or other third party material in this article are included in the article's Creative Commons licence, unless indicated otherwise in a credit line to the material. If material is not included in the article's Creative Commons licence and your intended use is not permitted by statutory regulation or exceeds the permitted use, you will need to obtain permission directly from the copyright holder. To view a copy of this licence, visit http://creativecommons. org/licenses/by/4.0/.

\section{References}

Armstrong CW, Foley NS, Tinch R, van den Hove S (2012) Services from the deep: steps towards valuation of deep sea goods and services. Ecosyst Serv 2:2-13

Assis J, Tyberghein L, Bosch S, Verbruggen H, Serrão EA, De Clerck O (2018) Bio-ORACLE v2. 0: extending marine data layers for bioclimatic modelling. Glob Ecol Biogeogr 27(3):277-284

Baccini A, Laporte N, Goetz SJ, Sun M, Dong H (2008) A first map of tropical Africa's above-ground biomass derived from satellite imagery. Environ Res Lett 3(4):045011. https://doi.org/10.1088/ 1748-9326/3/4/045011

Baussant T, Nilsen M, Ravagnan E, Westerlund S, Ramanand S (2017) Physiological responses and lipid storage of the coral Lophelia pertusa at varying food density. J Toxicol Environ Health Part A 80(5):266-284

Bell JJ, Bennett HM, Rovellini A, Webster NS (2018) Sponges to be winners under near-future climate scenarios. Bioscience 68(12):955-968. https://doi.org/10.1093/biosci/biy142

Benoist NM, Bett BJ, Morris KJ, Ruhl HA (2019) A generalised volumetric method to estimate the biomass of photographically surveyed benthic megafauna. Prog Oceanogr 178:102188. https://doi.org/10.1016/j.pocean.2019.102188

BODC (2015) https://www.bodc.ac.uk/resources/inventories/cruise_ inventory/report/11421/

Bodenmann A, Thornton B (2017) Generation of high-resolution three-dimensional reconstructions of the seafloor in color using a single camera and structured light. J Field Robot 34(5):833-851. https://doi.org/10.1002/rob

Bohnsack JA, Harper DE (1988) Length-weight relationships of selected marine reef fishes from the southeastern United States and the Caribbean. Technical memorandum 215. National Oceanic and Atmospheric Administration, National Marine Fisheries Service, Miami, Florida

Bolden IW, Sachs JP, Gagnonm AC (2019) Temporally-variable productivity quotients on a coral atoll: implications for estimates of reef metabolism. Mar Chem 20:p217. https://doi.org/10.1016/ j.marchem.2019.103707

Breiman L (2001) Random forests. Mach Learn 45:5-32. https://doi. org/10.1023/A:1010933404324

Buhl-Mortensen L, Vanreusel A, Gooday AJ, Levin LA, Priede IG, Buhl-Mortensen P, Gheerardyn H, King NJ, Raes M (2010) Biological structures as a source of habitat heterogeneity and biodiversity on the deep ocean margins. Mar Ecol Evolut Perspect 31:21-50. https://doi.org/10.1111/j.1439-0485.2010. 00359.x

Burrows, M. T., Kamenos, N. A., Hughes, D. J., Stahl, H., Howe, J. A., Tett, P. (2014). Assessment of carbon budgets and potential blue carbon stores in Scotland's coastal and marine environment. Scottish Natural Heritage Commissioned Report 761 
Cathalot C, Van Oevelen D, Cox TJ, Kutti T, Lavaleye M, Duineveld G, Meysman FJ (2015) Cold-water coral reefs and adjacent sponge grounds: hotspots of benthic respiration and organic carbon cycling in the deep sea. Front Mar Sci 2:1-12. https://doi. org/10.3389/fmars.2015.00037

Conti LA, Lim A, Wheeler AJ (2019) High resolution mapping of a cold-water coral mound. Sci Rep. https://doi.org/10.1038/ s41598-018-37725-x

Davies AJ, Duineveld GCa, LavaleyeBergman MSSMJN, Van Haren H, Roberts JM (2009) Downwelling and deep-water bottom currents as food supply mechanisms to the cold-water coral Lophelia pertusa (Scleractinia) at the Mingulay reef complex. Limnol Oceanogr 54:620-629. https://doi.org/10.4319/1o.2009. 54.2.0620

De Clippele LH, Gafeira J, Robert K, Hennige S, Lavaleye MS, Duineveld GCA, Huvenne VA, Roberts JM (2019) Geomorphological characteristics, percentage cover of live coral, mound and live coral delineation and predictive map of likelihood of live coral at the Mingulay reef Complex coral. PANGAEA. https:// doi.org/10.1594/PANGAEA.909237

De Clippele LH, Gafeira J, Robert K, Hennige S, Lavaleye MS, Duineveld GCA, Huvenne VA, Roberts JM (2017) Using novel acoustic and visual mapping tools to predict the small-scale spatial distribution of live biogenic reef framework in cold-water coral habitats. Coral Reefs 36:255-268. https://doi.org/10.1007/ s00338-016-1519-8

De Clippele LH, Huvenne VA, Molodtsova TN, Roberts JM (2019) The diversity and ecological role of non-scleractinian corals (Antipatharia and Alcyonacea) on scleractinian cold-water coral mounds. Front Mar Sci. https://doi.org/10.3389/fmars.2019. 00184

De Clippele LH, Huvenne VA, Orejas C, Lundälv T, Fox A, Hennige SJ, Roberts JM (2018) The effect of local hydrodynamics on the spatial extent and morphology of cold-water coral habitats at Tisler Reef Norway. Coral Reefs 37(1):253-266

de Froe E, Rovelli L, Glud RN, Maier SR, Duineveld G, Mienis F, Lavaleye M, van Oevelen D (2019) Benthic oxygen and nitrogen exchange on a cold-water coral reef in the north-east Atlantic ocean. Front Mar Sci. https://doi.org/10.3389/fmars.2019.00665

de Goeij JM, Lesser MP, Pawlik JR (2017) Nutrient fluxes and ecological functions of coral reef sponges in a changing ocean. Climate change, ocean acidification and sponges. Springer, Cham, pp 373-410

Dodds LA, Black KD, Orr H, Roberts JM (2009) Lipid biomarkers reveal geographical differences in food supply to the cold-water coral Lophelia pertusa (Scleractinia). Mar Ecol Prog Ser 397:113-124

Dodds LA, Roberts JM, Taylor AC, Marubini F (2007) Metabolic tolerance of the cold-water coral Lophelia pertusa (Scleractinia) to temperature and dissolved oxygen change. J Exp Mar Biol Ecol 349:205-214

Dornelas M, Madin JS, Baird AH, Connolly SR (2017) Allometric growth in reef-building corals. Proc $\mathrm{R}$ Soc B Biol Sci 284(1851):20170053

Douarin M, Sinclair DJ, Elliot M, Henry LA, Long D, Mitchison F, Roberts JM (2014) Changes in fossil assemblage in sediment cores from Mingulay reef complex (NE Atlantic): implications for coral reef build-up. Deep Res Part II Top Stud Oceanogr 99:286-296. https://doi.org/10.1016/j.dsr2.2013.07.022

Duineveld GC, Jeffreys RM, Lavaleye MS, Davies AJ, Bergman MJ, Watmough T, Witbaard R (2012) Spatial and tidal variation in food supply to shallow cold-water coral reefs of the Mingulay reef complex (Outer Hebrides, Scotland). Mar Ecol Prog Ser 444:97-115. https://doi.org/10.3354/meps09430
Elawady, M. (2015). Sparse Coral Classification Using Deep Convolutional Neural Networks. Available at: http://arxiv.org/ abs $/ 1511.09067$

Findlay HS, Hennige SJ, Wicks LC, Navas JM, Woodward EMS, Roberts JM (2014) Fine-scale nutrient and carbonate system dynamics around cold-water coral reefs in the northeast Atlantic. Sci Rep 4:3671. https://doi.org/10.1038/srep03671

Findlay HS, Wicks L, Moreno Navas J, Hennige HS, Huvenne V, Woodward EMS, Roberts JM (2013) Tidal downwelling and implications for the carbon biogeochemistry of cold-water corals in relation to future ocean acidification and warming. Glob Change Biol 19:2708-2719

Foley NS, van Rensburg TM, Armstrong CW (2010) The ecological and economic value of cold-water coral ecosystems. Ocean Coast Manag 53:313-326. https://doi.org/10.1016/j.ocecoaman. 2010.04.009

Freiwald A, Wilson JB (1998) Taphonomy of modern deep, coldtemperate water coral reefs. Historical Biol 13(1):37-52

Freiwald, A., Henrich, R. and Pätzold, J. (1997) Anatomy of a deepwater coral reef mound from Stjernsund, West Finnmark, northern Norway

Freiwald A, Wilson JB, Henrich R (1999) Grounding pleistocene icebergs shape recent deep-water coral reefs. Sed Geol 125(1-2): $1-8$

Glud RN (2008) Oxygen dynamics of marine sediments. Mar Biol Res 4(4):243-289. https://doi.org/10.1080/17451000801888726

Gomez C, Gori A, Weinnig A, Hallaj A, Keller A, Cordes E (2019) Effects of temperature increase on the metabolic performance of the cold-water coral Lophelia pertusa. International Deep Sea Coral Symposium, Cartagena, Colombia

Gori A, Reynaud S, Orejas C, Ferrier-Pagès C, Ferrier-Pages C (2015) The influence of flow velocity and temperature on zooplankton capture rates by the cold-water coral Dendrophyllia cornigera. J Exp Mar Biol Ecol 466:92-97. https://doi.org/10.1016/j.jembe. 2015.02.004

Guihen D, White M, Lundälv T (2012) Temperature shocks and ecological implications at a cold-water coral reef. Mar Biodivers Rec 5:e68

Hennige SJ, Wicks LC, Kamenos NA, Bakker DCE, Findlay HS, Dumousseaud C, Roberts JM (2014) Short-term metabolic and growth responses of the cold-water coral Lophelia pertusa to ocean acidification. Deep Sea Res Part II 99:27-35. https://doi. org/10.1016/j.dsr2.2013.07.005

Hennige SJ, Wicks LC, Kamenos NA, Perna G, Findlay HS, Roberts JM (2015) Hidden impacts of ocean acidification to live and dead coral framework. Proc Biol Sci R Soc 282(1813):20150990

Henry LA, Davies AJ, Roberts JM (2010) Beta diversity of cold-water coral reef communities off western Scotland. Coral Reefs 29:427-436. https://doi.org/10.1007/s00338-009-0577-6

Henry LA, Roberts JM (2007) Biodiversity and ecological composition of macrobenthos on cold-water coral mounds and adjacent off-mound habitat in the bathyal Porcupine Seabight, NE Atlantic. Deep-Sea Res Part I 54:654-672. https://doi.org/10. 1016/j.dsr.2007.01.005

Henry L-AA, Roberts JM (2014) Recommendations for best practice in deep-sea habitat classification: Bullimore et al. as a case study. ICES J Mar Sci 71:895-898. https://doi.org/10.1093/icesjms/ fst 175

IPCC, Masson-Delmotte, V., Zhai, P., Pörtner, H.O., Roberts, D., Skea, J., Shukla, P.R., Pirani, A., Moufouma-Okia, W., Péan, C., Pidcock, R. and Connors, S. (2018) Summary for policymakers

Johnson D, Adelaide Ferreira M, Kenchington E (2018) Climate change is likely to severely limit the effectiveness of deep-sea ABMTs in the North Atlantic. Mar Policy 87:111-122. https:// doi.org/10.1016/j.marpol.2017.09.034 
Jones CG, Lawton JH, Shachak M (1997) Positive and negative effects of organisms as physical ecosystem engineers. Ecology 78:1946-1957

Jones DOB, Yool A, Wei C, Henson SA (2014) Global reductions in seafloor biomass in response to climate change. Glob Change Biol 20(6):1861-1872. https://doi.org/10.1111/gcb.12480

Kazanidis G, Witte UFM (2016) The trophic structure of Spongosorites coralliophaga -coral rubble communities at two northeast Atlantic cold-water coral reefs. Mar Biol Res 12(9):932-947. https://doi.org/10.1080/17451000.2016.1216569

Kazanidis G, Henry LA, Roberts JM, Witte UFM (2016) Biodiversity of Spongosorites coralliophaga (Stephens, 1915) on coral rubble at two contrasting cold-water coral reef settings. Coral Reefs 35:193-208. https://doi.org/10.1007/s00338-015-1355-2

Kazanidis G, Oevelen DV, Veuger B, Witte UFM (2018) Deep-sea research part I unravelling the versatile feeding and metabolic strategies of the cold-water ecosystem engineer Spongosorites coralliophaga (Stephens, 1915). Deep Sea Res Part I 141:71-82. https://doi.org/10.1016/j.dsr.2018.07.009

Kazanidis G, Van Oevelen D, Veuger B, Witte UFM (2018) Ecophysiology data on the cold-water ecosystem engineer Spongosorites coralliophaga. British Oceanographic Data Centre - Natural Environment Research Council, UK

Kenyon NH, Akhmetzhanov AM, Wheeler AJ, van Weering TC, de Haas H, Ivanov MK (2003) Giant carbonate mud mounds in the southern Rockall Trough. Mar Geol 195(1-4):5-30

Khripounoff A, Caprais J, Bruchec JL, Rodier P, Noel P (2014) Deep cold-water coral ecosystems in the Brittany submarine canyons (Northeast Atlantic): hydrodynamics, particle supply, respiration, and carbon cycling. Limnol Oceanogr 59(1):87-98. https:// doi.org/10.4319/lo.2014.59.01.0087

Larsson AI, Lundälv T, van Oevelen D (2013) (a). Skeletal growth, respiration rate and fatty acid composition in the cold-water coral Lophelia pertusa under varying food conditions. Mar Ecol Prog Ser 483:169-184

Larsson AI, van Oevelen D, Purser A, Thomsen L (2013) Tolerance to long-term exposure of suspended benthic sediments and drill cuttings in the cold-water coral Lophelia pertusa. Mar Pollut Bull 70(1-2):176-188

Lesser MP, Slattery M (2020) Will coral reef sponges be winners in the anthropocene? Glob Change Biol 26(6):3202-3211. https:// doi.org/10.1111/gcb.15039

Lunden J, McNicholl C, Sears C, Morrison C, Cordes E (2014) Acute survivorship of the deep-sea coral Lophelia pertusa from the Gulf of Mexico under acidification, warming, and deoxygenation. Front Mar Sci 1:1-12. https://doi.org/10.3389/fmars.2014. 00078

Madin JS, Baird AH, Baskett ML, Connolly SR, Dornelas MA (2020) Partitioning colony size variation into growth and partial mortality. Biol Lett. https://doi.org/10.1098/rsbl.2019.0727

Maier SR, Bannister RJ, van Oevelen D, Kutti T (2020) Seasonal controls on the diet, metabolic activity, tissue reserves and growth of the cold-water coral Lophelia pertusa. Coral Reefs 39(1):173-187

Maier SR, Kutti T, Bannister RJ, van Breugel P, van Rijswijk P, van Oevelen D (2019) Survival under conditions of variable food availability: resource utilization and storage in the cold-water coral Lophelia pertusa. Limnol Oceanogr 64(4):1651-1671

Marine Scotland Science (2016) Scottish Marine Protected Areas Socioeconomic Monitoring 2016 Report. https://www.gov.scot/ publications/scottish-marine-protected-areas-socioeconomicmonitoring/

Morato T, González-Irusta JM, Dominguez-Carrió C, Wei CL, Davies A, Sweetman AK, Taranto GH, Beazley L, García-Alegre A, Grehan A, Laffargue P (2020) Climate-induced changes in the suitable habitat of cold-water corals and commercially important deep-sea fishes in the North Atlantic. Glob Change Biol 26(4):2181-2202

Moreno-Navas J, Miller PL, Henry L-A, Hennige SJ, Roberts JM (2014) Ecohydrodynamics of cold-water coral reefs: a case study of the Mingulay reef complex (Western Scotland). PLoS ONE 9(5):e98218

Naumann MS, Orejas C, Ferrier-Pagès C (2014) Species-specific physiological response by the cold-water corals Lophelia pertusa and Madrepora oculata to variations within their natural temperature range. Deep Sea Res Part II 99:36-41

Roberts JM, Brown CJ, Long D, Wilson CK, Bates CR, Mitchell A, Service M (2004). Mapping INshore coral habitats, the MINCH project. Scottish association for marine science report to the Scottish executive and Scottish natural heritage. 115p

Roberts JM, Cairns SD (2014) Cold-water corals in a changing ocean. Curr Opin Environ Sustain 7:118-126. https://doi.org/10.1016/j. cosust.2014.01.004

Roberts JM, Davies AJ, Henry LA, Dodds LA, Duineveld GCA, Lavaleye MSS, Maier C, Van Soest RWM, Bergman MJN, Hühnerbach V, Huvenne VAI (2009) Mingulay reef complex: an interdisciplinary study of cold-water coral habitat, hydrography and biodiversity. Mar Ecol Prog Ser 397:139-151. https://doi. org/10.3354/meps08112

Roberts JM, Wheeler AJ, Freiwald A (2006) Reefs of the deep: the biology and geology of cold-water coral ecosystems. Science 80(312):543-547. https://doi.org/10.1126/science.1119861

Roberts JM, Brown CJ, Long D, Bates CR (2005) Acoustic mapping using a multibeam echosounder reveals cold-water coral reefs and surrounding habitats. Coral Reefs 24(4):654-669

Rovelli L, Attard KM, Bryant LD, Flögel S, Stahl H, Roberts JM, Linke P, Glud RN (2015) Benthic O2 uptake of two cold-water coral communities estimated with the non-invasive eddy correlation technique. Mar Ecol Prog Ser 525:97-104. https://doi.org/ 10.3354/meps 11211

Rowden AA, Anderson OF, Georgian SE, Bowden DA, Clark MR, Pallentin A, Miller A (2017) High-resolution habitat suitability models for the conservation and management of vulnerable marine ecosystems on the Louisville Seamount chain south Pacific Ocean. Front Mar Sci. https://doi.org/10.3389/fmars. 2017.00335

Rowe G, Boland G, Escobar Briomes E, Cruz-Kaegi M, Newton A, Piepenburgh D, Walsh I, Deming J (1997) Sediment community biomass and respiration in the Northeast Water Polynya, Greenland: a numerical simulation of benthic lander and spade core data. J Mar Syst 10(1-4):497-515

Rueden CT, Schindelin J, Hiner MC, DeZonia BE, Walter AE, Arena ET, Eliceiri KW (2017) ImageJ2: imageJ for the next generation of scientific image data. BMC Bioinform 18:529

Scanes E, Kutti T, Fang JKH, Johnston EL, Ross PM, Bannister RJ (2018) Mine waste and acute warming induce energetic stress in the deep-sea sponge Geodia atlantica and coral Primnoa resedeaformis; results from a mesocosm study. Front Mar Sci 5:1-14. https://doi.org/10.3389/fmars.2018.00129

Skropeta D (2008) Deep-sea natural products. Nat Prod Rep 25:1131-1166. https://doi.org/10.1039/b808743a

Stevenson A, Archer SK, Schultz JA, Dunham A, Marliave JB, Martone P, Harley CDG (2020) Warming and acidification threaten glass sponge Aphrocallistes vastus pumping and reef formation. Sci Rep 10(1):1-11. https://doi.org/10.1038/s41598020-65220-9

Stratmann T, Soetaert K, Wei C, Lin Y, Oevelen DV (2019) The SCOC database, a large, open, and global database with sediment community oxygen consumption rates. Sci Data. https://doi.org/10.1038/s41597-019-0259-3

Suess E (1980) Particulate organic carbon flux in the oceans-surface productivity and oxygen utilization. Nature 288:260-263 
Sweetman AK, Thurber AR, Smith CR, Levin LA, Mora C, Wei C-L, Gooday AJ, Jones DOB, Rex M, Yasuhara M, Ingels J, Ruhl HA, FriederDanovaro CAR, Würzberg L, Baco A, Grupe BM, Pasulka A, Meyer KS, Dunlop KM, Henry L-A, Roberts JM (2017) Major impacts of climate change on deep-sea benthic ecosystems. Elem Sci Anthr. https://doi.org/10.1525/elementa. 203

Takeshita Y, Cyronak T, Martz TR, Kindeberg T, Andersson AJ (2018) Coral reef carbonate chemistry variability at different functional scales. Front Mar Sci 22(5):175. https://doi.org/10. 3389/fmars.2018.00175

Therkildsen MS, Lomstein BA (1993) Seasonal variation in net benthic C-mineralization in a shallow estuary. FEMS Microbiol Ecol 12(2):131-142. https://doi.org/10.1111/j.1574-6941.1993. tb00025.x

Thornton B, Bodenmann A, Pizarro O, Williams SB, Friedman A, Nakajima R, Takai K, Motoki K, Watsuji TO, Hirayama H, Matsui Y (2016) Biometric assessment of deep-sea vent megabenthic communities using multi-resolution 3D image reconstructions. Deep Sea Res Part I 116:200-219. https://doi. org/10.1016/j.dsr.2016.08.009

Thresher RE, Guinotte JM, Matear RJ, Hobday AJ (2015) Options for managing impacts of climate change on a deep-sea community. Nat Clim Change 5(7):635-639

Titschack J, Baum D, De Pol-Holz R, Lopez Correa M, Forster N, Flögel S, Hebbeln D, Freiwald A (2015) Aggradation and carbonate accumulation of Holocene Norwegian cold-water coral reefs. Sedimentology 62(7):1873-1898

Tyberghein L, Verbruggen H, Pauly K, Troupin C, Mineur F, De Clerck O (2012) Bio-ORACLE: A global environmental dataset for marine species distribution modelling. Glob Ecol Biogeogr 21:272-281

Vad J, Orejas C, Moreno-Navas J, Findlay HS, Roberts JM (2017) Assessing the living and dead proportions of cold-water coral colonies: implications for deep-water marine protected area monitoring in a changing ocean. Peer J 5:e3705. https://doi.org/ 10.7717/peerj. 3705

van Oevelen D, Duineveld DG, Lavaleye M, Mienis F, Soetaert K, Heip CHR (2009) The cold-water coral community as a hot spot for carbon cycling on continental margins: a food-web analysis from Rockall Bank (northeast Atlantic). Limnol Oceanogr 54:1829-1844. https://doi.org/10.4319/lo.2009.54.6.1829

Wei CL, Rowe GT, Escobar-Briones E, Boetius A, Soltwedel T, Caley MJ, Soliman Y, Huettmann F, Qu F, Yu Z, Pitcher CR (2010) Global patterns and predictions of seafloor biomass using random forests. PLoS ONE 5(12):e15323

Wheeler AJ, Beyer A, Freiwald A, De Haas H, Huvenne VAI, Kozachenko M, Olu-Le Roy K, Opderbecke J (2007) Morphology and environment of cold-water coral carbonate mounds on the NW European margin. Int J Earth Sci 96:37-56. https://doi. org/10.1007/s00531-006-0130-6

White M, Wolff GA, Lundälv T, Guihen D, Kiriakoulakis K, Lavaleye M, Duineveld G (2012) Cold-water coral ecosystem (Tisler Reef, Norwegian shelf) may be a hotspot for carbon cycling. Mar Ecol Prog Ser 465:11-23. https://doi.org/10.3354/ meps09888

Windholz M, Budavari S, Blumetti RF, Otterbein ES (1983) The merck index, 10th edn. Merck and Co., Inc., Rahway

Zibrowius H (1980) Les Scléractiniaires de la Méditerranée et de l'Atlantique nord-oriental. Mémoires de l'Institut océanographique, Monaco

Zibrowius H (1982) Taxonomy in ahermatypic scleractinian corals. Palaeontogr Am 54:80-85

Zibrowius H (1984) Taxonomy in ahermatypic scleractinian corals. Paleontogr Am 54:80-85

Publisher's Note Springer Nature remains neutral with regard to jurisdictional claims in published maps and institutional affiliations. 